OPEN ACCESS

Edited by:

Christopher Michael DeGiorgio,

University of California, Los Angeles,

United States

Reviewed by:

Lisa M. Bateman,

Columbia University, United States

Ding Ding,

Fudan University, China

*Correspondence:

Gordon F. Buchanan

gordon-buchanan@uiowa.edu

Specialty section:

This article was submitted to

Epilepsy,

a section of the journal

Frontiers in Neurology

Received: 10 September 2018 Accepted: 27 November 2018 Published: 11 December 2018

Citation:

Purnell BS, Thijs RD and Buchanan GF (2018) Dead in the Night: Sleep-Wake and Time-Of-Day Influences on Sudden Unexpected

Death in Epilepsy.

Front. Neurol. 9:1079.

doi: 10.3389/fneur.2018.01079

\section{Dead in the Night: Sleep-Wake and Time-Of-Day Influences on Sudden Unexpected Death in Epilepsy}

\author{
Benton S. Purnell ${ }^{1,2,3}$, Roland D. Thijs ${ }^{4,5,6}$ and Gordon F. Buchanan ${ }^{1,2,3 *}$ \\ ${ }^{1}$ Department of Neurology, Carver College of Medicine, University of lowa, lowa City, IA, United States, ${ }^{2}$ Neuroscience \\ Program, University of lowa, lowa City, IA, United States, ${ }^{3}$ Iowa Neuroscience Institute, Carver College of Medicine, \\ University of lowa, lowa City, IA, United States, ${ }^{4}$ Stichting Epilepsie Instellingen Nederland (SEIN), Heemstede, Netherlands, \\ ${ }^{5}$ NIHR University College London Hospitals Biomedical Research Centre, UCL Institute of Neurology, London, \\ United Kingdom, ${ }^{6}$ Department of Neurology, LUMC Leiden University Medical Center, Leiden, Netherlands
}

Sudden unexpected death in epilepsy (SUDEP) is the leading cause of epilepsy-related death in patients with refractory epilepsy. Convergent lines of evidence suggest that SUDEP occurs due to seizure induced perturbation of respiratory, cardiac, and electrocerebral function as well as potential predisposing factors. It is consistently observed that SUDEP happens more during the night and the early hours of the morning. The aim of this review is to discuss evidence from patient cases, clinical studies, and animal research which is pertinent to the nocturnality of SUDEP. There are a number of factors which might contribute to the nighttime predilection of SUDEP. These factors fall into four categories: influences of (1) being unwitnessed, (2) lying prone in bed, (3) sleep-wake state, and (4) circadian rhythms. During the night, seizures are more likely to be unwitnessed; therefore, it is less likely that another person would be able to administer a lifesaving intervention. Patients are more likely to be prone on a bed following a nocturnal seizure. Being prone in the accouterments of a bed during the postictal period might impair breathing and increase SUDEP risk. Sleep typically happens at night and seizures which emerge from sleep might be more dangerous. Lastly, there are circadian changes to physiology during the night which might facilitate SUDEP. These possible explanations for the nocturnality of SUDEP are not mutually exclusive. The increased rate of SUDEP during the night is likely multifactorial involving both situational factors, such as being without a witness and prone, and physiological changes due to the influence of sleep and circadian rhythms. Understanding the causal elements in the nocturnality of SUDEP may be critical to the development of effective preventive countermeasures.

Keywords: SUDEP, sleep, epilepsy, circadian rhythms, breathing

\section{INTRODUCTION}

The leading cause of epilepsy-related death in patients with refractory epilepsy is sudden unexpected death in epilepsy [SUDEP; (1-5)]. Among neurological conditions, SUDEP is second only to stroke in terms of years of potential life lost to disease (4). There are no effective ways to reliably predict or prevent SUDEP $(3,5-8)$. SUDEP is hypothesized to be the result of predisposing factors in the patient and seizure induced perturbation of respiratory, cardiac, and electrocerebral 
function (3, 5, 7-9). In cases of SUDEP which have been recorded in an epilepsy monitoring unit, respiratory arrest appears to be the primary cause of death as terminal apnea precedes terminal asystole in each case (10).

It is consistently observed that SUDEP happens more during the night and the early hours of the morning $(2,10-14)$. Lamberts et al. observed that $62 \%$ of SUDEP cases happened between midnight and noon and that $58 \%$ of SUDEP cases were sleeprelated (12). In SUDEP cases occurring in epilepsy monitoring units, $87.5 \%$ of deaths were observed to happen during the night (10). In a meta-analysis of definite, probable, and possible SUDEP, Ali et al. observed that $69.3 \%$ of SUDEP cases were presumed to have happened during sleep (13). Furthermore, patients who die of SUDEP are about twice as likely to have nocturnal seizures than those who did not die of $\operatorname{SUDEP}(12,14)$. The increased nocturnal incidence of SUDEP is often attributed to an increased risk of SUDEP during sleep; however, there are a number of factors which might contribute to the nighttime predilection of SUDEP. These factors fall into four categories: influences of (1) being in the absence of a witness, (2) lying prone in bed, (3) sleep-wake state, and (4) circadian rhythms. A consistent issue for determining the cause of the nocturnality of SUDEP is disentangling the potential effect of sleep from the effect of circadian rhythms, not to mention complicating factors such as being without a witness and prone in bed. In humans, sleep typically happens during the night. Consequently, circadian rhythms and homeostatic sleep processes are often considered together; nevertheless, these are distinct processes. Indeed, sleep and circadian rhythmicity alter physiologic processes, such as cardiac and respiratory function, independent of one another (15-20). For a comprehensive meta-analysis of SUDEP cases which consider sleep state or time-of-day as a potential risk factor, please see (13) and (21). The aim of this review is to discuss evidence from patient cases, clinical studies, and animal research which is pertinent to the nocturnality of SUDEP and to consider the implications for clinicians, patients, and the development of preventative strategies. The definition of SUDEP established by Nashef et al. is used for the purposes of this review unless otherwise specified (22).

\section{BEING IN THE ABSENCE OF A WITNESS}

Most SUDEP cases are unwitnessed $(12,23)$. This suggests that the presence of someone who could intervene after a seizure may be protective against $\operatorname{SUDEP}(2,12)$. Seizures which happen during the hours of the day usually occupied by sleep are more likely to be unwitnessed than those occurring during wakefulness $(24,25)$. Increasing nocturnal supervision by the use of monitoring devices, regular checks or having someone else sleep in the same room is associated with a decreased risk of SUDEP $(2,6,14)$. The mechanism by which the presence of another person might differentiate survival from SUDEP is not clear; however, nursing interventions such as repositioning and supplemental oxygen administration are associated with shorter seizures, a reduction in postictal EEG suppression and improved respiratory function $(23,26)$.
Given the potential for life saving interventions in the time after a severe seizure, the development and distribution of devices capable of predicting seizures and/or detecting seizures and alerting others holds great promise for reducing the rate of nighttime SUDEP. Accurate seizure forecasting would potentially allow for preventative measures to be taken to reduce the chance that an approaching seizure results in SUDEP. Unfortunately, seizure forecasting has proved quite challenging (27).

Conversely, automated seizure detection devices have the potential to detect convulsive seizures with some degree of reliability $(28,29)$. While EEG is still the most reliable modality for seizure detection, an EEG apparatus is likely not realistic in the home setting. Additionally, while over-night video monitoring improves the detection of nocturnal seizures in a clinical setting it may not be reasonable to expect someone to monitor patients in this way in the home setting (30). The development of automated seizure detection algorithms which use video data to trigger an alarm in response to seizures have considerable promise for reducing the rate of nocturnal SUDEP (31). Unfortunately, there is a scarcity of long-term home-based data to support the efficacy of nocturnal monitoring and seizure detection devices $(32,33)$. Furthermore, reliable alarms only have the potential to prevent death if there is another person who is able to quickly intervene in response to the alarm. Lastly, increased monitoring of at risk patients by caregivers or devices is unlikely to be successful in all cases as SUDEP has been known to occur even in the presence of medical professionals after the patient announced "I'm going to have a seizure" $(34,35)$.

\section{LYING PRONE IN BED}

In the majority of SUDEP cases, the victim is found in the prone position regardless of the supposed vigilance state of seizure origin (36-38); however, possible, probable and definite SUDEP cases which are inferred to have happened during sleep are more likely to be found prone than those which are inferred to have happened during wakefulness [Figure 1B, (13)]. Furthermore, non-fatal convulsive seizures infrequently result in a patient inverting into the prone position (39). It is generally agreed that ending a convulsive seizure in the prone position may contribute to $\operatorname{SUDEP}(39,40)$. The most plausible explanation for this is that breathing during the postictal period is more likely to be impaired while prone consequent to upper airway occlusion or asphyxiation against the substrate on which the body is positioned (40-42).

The nose and mouth being pressed against pillows or the other accouterments of beds may impair postictal respiration by increasing inspiratory resistance and by causing the patient to rebreathe the trapped air $(23,43)$. Under normal circumstances, this obstruction of the airway would arouse the person and cause them to reposition, this response may not be possible in the time following a seizure $(39,44,45)$. "Anti-suffocation" pillows are currently available; unfortunately, there is a paucity of evidence as to their effectiveness $(23,46)$.

Another sudden death condition, sudden infant death syndrome (SIDS) shares common features with SUDEP, 
A

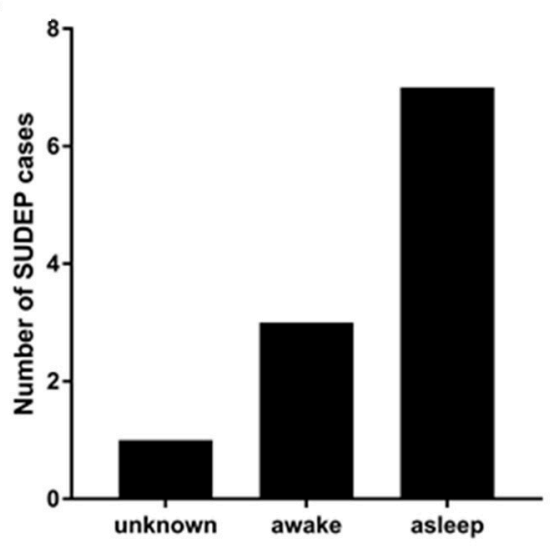

C

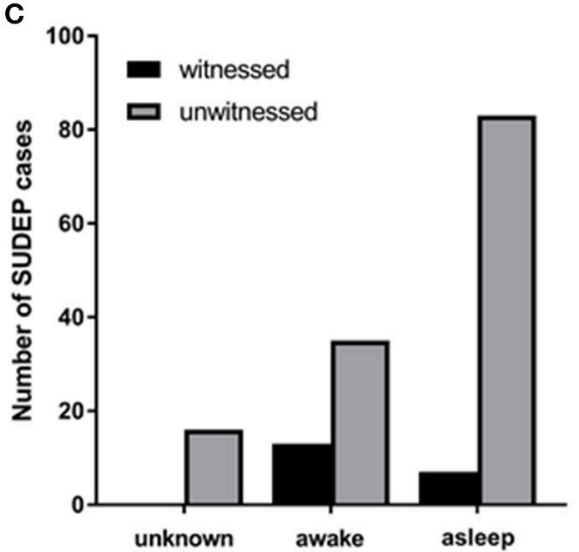

B

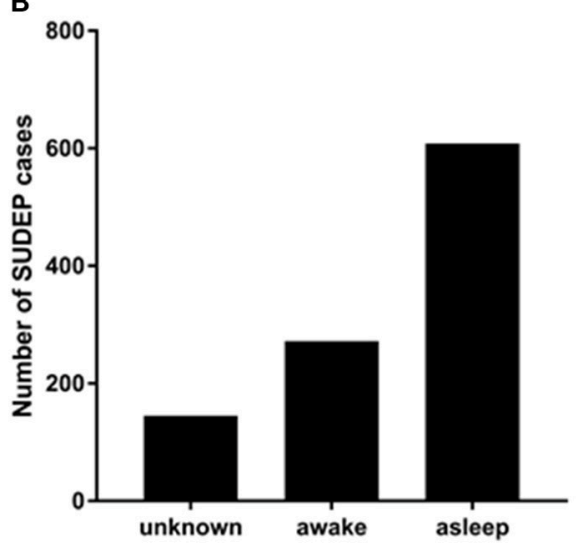

D

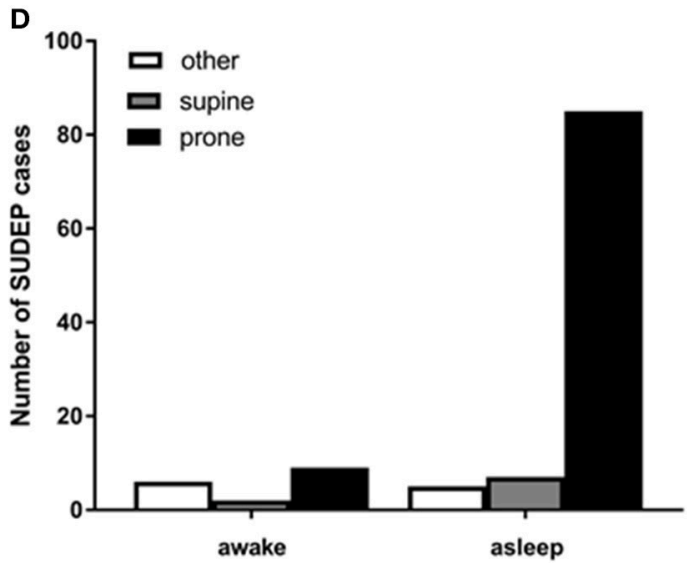

FIGURE 1 | (A) Numbers of SUDEP cases in different vigilance states captured by EEG in the mortality in epilepsy monitoring units study (MORTEMUS: redrawn with permission from Ryvlin et al. (10). (B) numbers of sleep-related definite, possible, and probable SUDEP cases [redrawn with permission from Ali et al. (13)]; (C) numbers of witnessed and unwitnessed SUDEP cases in sleep and wakefulness [redrawn with permission from Lamberts et al. (12)]. (D) numbers of definite, possible, and probable SUDEP cases in sleep and wakefulness and in different body positions [redrawn with permission from Ali et al. (13)].

including that patients are often found prone immediately following nighttime rest. SIDS rates were reduced significantly by the "Back to Sleep" campaign, which encourages care givers to place infants supine to sleep (47). A similar initiative has been proposed to reduce SUDEP rates (48); however, it is not clear whether sleeping in a supine position would be meaningfully protective against SUDEP as body position may change following a convulsive seizure (39).

\section{SLEEP}

Sleep alters respiratory, cardiac, and electrocerebral physiology in ways that may be relevant to SUDEP. During sleep, airway patency is decreased thereby increasing airway resistance and increasing the likelihood of airway occlusion $(49,50)$. Inspiratory drive is lower during non-rapid eye movement (NREM) sleep and lowest during rapid eye movement (REM) sleep (51). Chemical stimuli potently regulate breathing. Failure of the respiratory system to respond to rising $\mathrm{CO}_{2}$ and falling $\mathrm{O}_{2}$ levels consequent to seizure induced respiratory dysregulation is theorized to be important in SUDEP etiology. $\mathrm{CO}_{2}$ levels are higher during sleep $(17,51)$. The hypercapnic ventilatory response is attenuated in NREM sleep in comparison to wakefulness (51-55). The respiratory response to hypoxia is decreased in both NREM and REM sleep (56). Interestingly, the hypoxic ventilatory response of women is less affected by sleep than men (57). This difference in responsiveness to $\mathrm{O}_{2}$ depletion during sleep may be responsible for the decreased risk of definite, possible, and probable SUDEP in females $(58,59)$. Seizures which occur during sleep are associated with lower periictal blood oxygenation (60).

Cardiac and autonomic activity is also modulated by sleep in ways which are potentially relevant to $\operatorname{SUDEP}(61,62)$. QT interval is longer during sleep than it is during wakefulness (15). It is hypothesized that a dramatic shift from parasympathetic to sympathetic drive may have a role in the dysregulation of cardiorespiratory function in SUDEP (63).

Sleep disordered breathing may also play a meaningful role in the nocturnality of SUDEP. Refractory epilepsy patients are at an increased risk of sleep disordered breathing, particularly 
obstructive sleep apnea [OSA; $(64,65)]$. OSA increases a patient's risk of sudden cardiac death (66). Interestingly, sudden cardiac death in patients with obstructive sleep apnea happens more during the night which is similar to the temporal distribution of SUDEP but unlike that of sudden cardiac death in the general population which tends to happen more during the morning $(66,67)$. Obstructive sleep apnea is associated with autonomic dysfunction and lower resting oxygen saturation which might increase a patient's vulnerability to SUDEP (68-70). Whether OSA is increased in SUDEP cases has not been studied yet.

It is generally agreed that NREM sleep facilitates the occurrence of seizures and that seizures rarely occur during REM sleep $(71,72)$. Seizures which occur during sleep are longer and more likely to evolve into focal to bilateral tonic-clonic seizures (73). It is unclear whether the incidence of focal to bilateral tonic-clonic seizures among those with nocturnal seizures can be explained by the lower seizure threshold during sleep as this could also attributed to differences in epilepsy etiology (e.g., nocturnal seizures are more common in frontal lobe epilepsy) $(74,75)$. Regardless, the increased risk of a sleep-related seizure generalizing may confer an increased risk of SUDEP. Seizures which originate from sleep have more severe perturbation of cardiac activity (76). In an analysis of non-fatal seizures in patients who went on to die of SUDEP it was found that SUDEP victims had a larger surge in heart rate following seizures which happen during sleep in comparison to the seizures of patients who did not die of definite or probable SUDEP (63). It is not clear whether postictal generalized EEG suppression, a state which might facilitate SUDEP, is meaningfully altered by vigilance state of seizure origin. Some studies have observed that sleep increases the probability and duration of postictal generalized EEG suppression (60,77-80). Conversely, other studies have not seen any association between sleep and postictal EEG suppression (81-83). In summary, there is some evidence to suggest that seizures which originate during sleep have different physiologic consequences than wake seizures in ways that are potentially meaningful to SUDEP.

The inherently unpredictable nature of SUDEP makes it difficult to study in humans; however, evoked seizures in animal models allow the physiological sequelae of seizures to be studied at any permutation of circadian phase and sleep state. Seizures which are induced during NREM sleep using maximal electroshock (MES) are longer, more severe, and more likely to result in death by seizure induced respiratory arrest than seizures induced during wakefulness (84). Non-fatal MESinduced seizures during NREM sleep also result in longer PGES, a greater degree of respiratory suppression, and longer apnea than seizures induced during wakefulness (84). Seizures induced in REM sleep in this model are universally fatal (84). The increased mortality seen after seizures induced during REM sleep is interesting given that seizures are less common during REM sleep $(72,85)$; however, this may not be true in some rodent models where REM sleep and the associated hippocampal theta rhythm might make seizures more likely (86). In one genetic mouse model with spontaneous seizures escalating sleep deficits preceded the fatal seizure suggesting that chronic sleep disturbances might play a role in SUDEP pathophysiology (87).
Because SUDEP is so frequently unobserved and rarely captured on EEG, it is not possible to determine the sleep state of origin for the fatal seizure in most cases. Patients who died of SUDEP are more likely to have had a nocturnal pattern of seizures and to have a history of seizures originating during sleep $(12,30,63)$. As discussed above, meta-analyses of unwitnessed SUDEP cases classify a SUDEP case as being "sleep-related" if it happened at night and in the general vicinity of a bed. These criteria are suboptimal; notwithstanding, using these criteria, a majority of SUDEP cases are "sleep-related" [Figures 1A-D, $(12,13,37)]$. Due to the presence of EEG at the onset of the fatal seizure, the insights provided by the mortality in epilepsy monitoring units study (MORTEMUS) are crucial to teasing apart the role of sleep in SUDEP. In this study, seven of the 10 cases for which sleep state could be determined occurred during sleep (1 during REM, 1 during stage 1, 2 in stage 2, and 3 in sleep stages 3 or 4; Figure 1A, (10)).

\section{CIRCADIAN RHYTHMS}

Circadian rhythmicity affects breathing independently of sleep state (17-20). Humans that are subjected to a constant routine paradigm, which spreads sleep and activity through the $24 \mathrm{~h}$ day, exhibit alterations in breathing at different times of day regardless of their sleep-wake state $(16,88,89)$. Animal studies also demonstrate circadian differences in breathing $(90,91)$. Diurnal organisms, such as humans, are more active during the day and have greater ventilation during the day $(88,92)$. Conversely, nocturnal organisms such as rodents, which are more active during the night, display increased ventilation during the night $(17,91)$.

In humans, the hypercapnic ventilatory response is higher during the morning and afternoon but decreases substantially during the night $(16,88)$. There are also circadian differences in sensitivity to $\mathrm{CO}_{2}$ in rodents with a decrease in sensitivity during the day (90). The hypoxic ventilatory response is regulated in a circadian fashion in humans with greater sensitivity during the day $(88,92,93)$; however, in rodents the response to hypoxic conditions is coupled to metabolism which changes in a circadian fashion in such a way that there are no net differences in the response to hypoxia at different times of day (91). The respiratory changes associated with seizures alter blood gas levels (94-97). Differences in how breathing responds to changes in blood gas levels at different times of day may alter a patient's ability to respond to seizure-induced respiratory changes. Lastly, respiratory tissues such as the larynx, trachea, and lung have peripheral circadian oscillators which operate under the purview of the central oscillator in the suprachiasmatic nuclei (SCN; 97). Bilateral SCN lesion disables the peripheral oscillators in these tissues as does genetic deletion of the clock genes cryptochrome 1 and 2 (98).

Circadian oscillations in baseline breathing, respiratory response to challenges, and clock gene expression in peripheral tissues are meaningful for a variety of disease states. The airway occlusion which is seen in sleep apnea is exacerbated by circadian changes in airway patency (99). Asthma is often worsened 
at night and respiratory irritants and allergens cause worse respiratory distress at this time (100-102). Chronic obstructive pulmonary disease symptoms are altered by circadian phase and these patients are more likely to require intubation in the morning (103). SIDS is thought to result, in part, from respiratory failure and occurs predominantly at night $(104,105)$.

The SCN is thought to play a role in autonomic regulation and thus explain why circadian changes may also impact cardiovascular control (106, 107); however, patients with impaired function of the SCN appeared to have similar cardiac function during sleep in comparison to healthy controls (108). Reduced heart rate variability (HRV) is an established risk factor for sudden cardiac death (109) and has been implicated in SUDEP risk although the few case-controls studies that have been published have conflicting findings (110-112). HRV is subject to circadian regulation in addition to the modulating effect of sleep state $(113,114)$. Day-night HRV dynamics appear to be altered in epilepsy patients; however, without identifying the role of sleep state or employing a forced desynchrony paradigm to isolate the influences of sleep state from circadian ones, it is difficult to state categorically whether this effect is mediated by sleep state or due to an independent circadian effect $(115,116)$. Cardiac responses to stimuli which are known to elicit a vagal response, such as compression of the eye, are regulated in a circadian fashion with the largest responses coming in late night and the early hours of the morning (117). QT lengthening or shortening may lower the threshold for ventricular fibrillation. Seizure-induced ventricular fibrillation may be seen in a minority of (near) SUDEP cases $(118,119)$. QT interval is modulated by both sleep state and circadian phase with QT intervals being longer during sleep and later in part of the night $(15,120)$.

It is well appreciated that seizures and interictal epileptiform discharges are regulated in a circadian manner (121-126). Analysis of seizure type, seizure timing, and sleep state of seizure origin indicates that sleep state and time-of-day independently affect seizures $(124,127)$. The influences of sleep state and circadian rhythms are also dependent on the site of seizure origin (128). It is unclear why the location of the seizure onset zone would alter the circadian distribution of seizures; however, it is known that different brain areas respond differently to the progression of circadian time (129).

Recently, infradian patterns in seizures have been identified which were previously underappreciated (130). These multidian rhythms have an influence on the occurrence of seizures which is comparable in strength to that of circadian phase. It is not clear whether seizures that happen at different points in these infradian oscillations are more likely to cause cardiorespiratory complications.

There are day-night differences in seizure severity and susceptibility consequent to DBA/2 audiogenic seizures and electrically induced seizures (131). It is postulated that these differences are causally related to day-night variations in serotonin and norepinephrine levels in different brain areas $(131,132)$. It is unclear on the basis of this study if there are any day-night differences in seizure induced death and whether these differences are independent of seizure severity. Furthermore, whether these differences are endogenously circadian, as opposed to being due to differential lighting conditions, was not investigated (131).

The only published data on the time-of-day of spontaneous death in an animal model of seizure induced death is from Kv1.1 null mice (133). These mice exhibit spontaneous seizures originating in the temporal lobe and typically die consequent to a seizure before 10 weeks of age. Kv1.1 null mice have an attenuated circadian rhythm in cardiac activity and the majority of their deaths occur during the night with peaks in mortality at the light/dark transition points [Figure 2, (133)]. This study did not monitor the vigilance state of the animal at the time of the fatal seizure, so it is impossible to determine whether this is an effect of sleep, circadian time, or both.

Seizures induced by MES during the day, the rodent inactive phase, are similar to seizures induced during the night in terms of duration and severity; however, MES seizures induced in the day during sleep resulted in a greater degree of postictal respiratory suppression (Figure 3, (134)). Seizures induced during this time also resulted in prolonged EEG suppression. This effect was even greater when seizures were also induced during sleep (134). Two caveats to this data are that only two time points were compared, and these experiments were conducted with the animals in a light-dark cycle environment. A broader sampling of time points throughout the $24 \mathrm{~h}$ day and conducting experiments in constant darkness, i.e., in the absence of circadian entraining light cues, may reveal a different temporal pattern.

SUDEP victims are more likely to have a nocturnal pattern of seizures $(12,14)$. Presently, it is impossible to determine whether this effect is driven by circadian rhythms or homeostatic sleep processes. Epilepsy surgery candidates, the population at the highest risk of SUDEP, have decreased HRV during the night compared to healthy controls (116). SUDEP is not uniformly distributed throughout the $24 \mathrm{~h}$ day (12). SUDEP presumed to have happened during sleep most commonly occurred between 0400 and 0800. SUDEP which is presumed to have happened during wakefulness most commonly occurred between the 0800

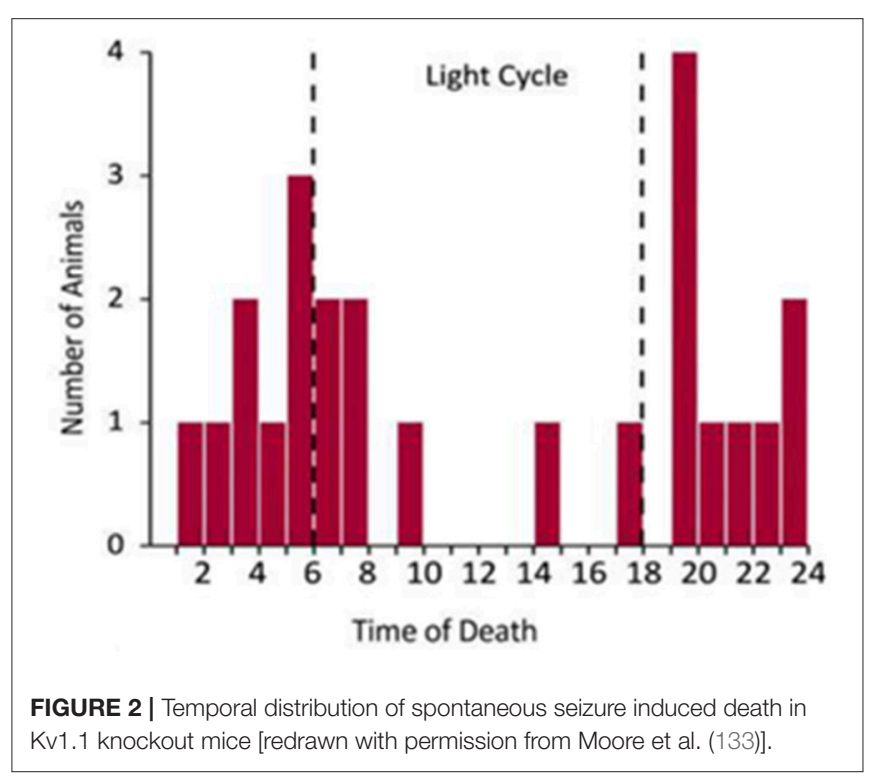




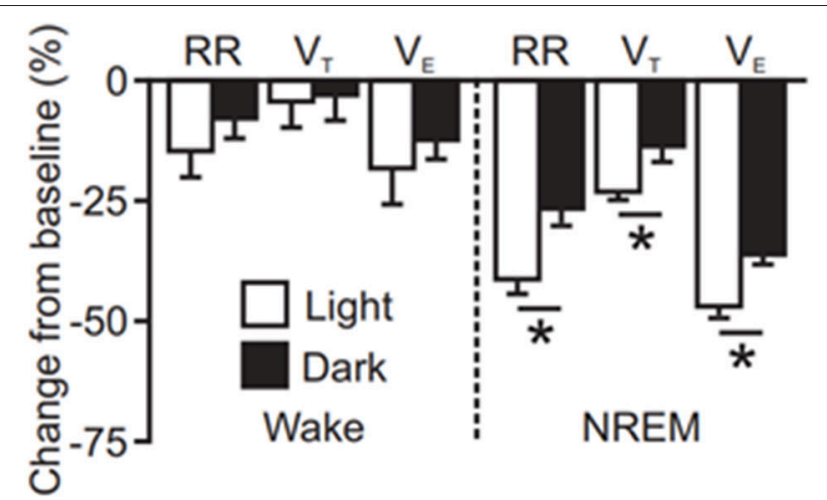

FIGURE 3 | Quantification of seizure induced suppression of breathing (RR; respiratory rate, $V_{\mathrm{T}}$; tidal volume, $\mathrm{V}_{\mathrm{E}}$; minute ventilation) following maximal electroshock seizures induced during wakefulness or non-rapid eye movement sleep (NREM) at different times of day [redrawn with permission from Purnell et al. (134)]. ${ }^{*} P<0.05$.

and 1200.The increased risk of seizures between 0400 and 1,200 is interesting as it suggests that there may be a circadian component to SUDEP which occurs independent of sleep state. If the nocturnality of SUDEP was attributable to sleep factors alone it would be expected that SUDEP frequency would decrease dramatically after 0800 when most people are no longer sleeping. In the MORTEMUS of SUDEP occurring in epilepsy monitoring units, most deaths occurred during the night. Conversely, most cases of near-SUDEP occurred during the day (10).

\section{POTENTIAL MECHANISMS}

\section{Serotonin}

In the central nervous system, serotonergic neurons are found in the raphe nuclei along the midline of the brainstem (135). Serotonergic neurotransmission modulates breathing, sleep-wake regulation, circadian rhythmicity, and seizures (136-139). Neuronal activity in the raphe nuclei is highest during wakefulness, reduced during NREM sleep, and almost entirely silent during REM sleep (140). Serotonin levels vary depending on circadian phase in areas such as the dorsal raphe, locus coeruleus, and hippocampus [Figure 4, (132, 141, 142, 149)]. Seizures suppress serotonergic neurotransmission in the ictal and the postictal period (150). Increases in serotonergic neurotransmission is a critical component of the arousal response to inspired $\mathrm{CO}_{2}$ (151-153). Stable breathing requires serotonergic neurotransmission (138). Seizure induced disruption of normal serotonergic arousal mechanisms may prevent the normal arousal response to $\mathrm{CO}_{2}$ in the postictal period and facilitate death (105).

In epilepsy patients, selective serotonin reuptake inhibitors (SSRI) reduce seizure associated hypoxemia (95). Larger seizure induced changes in serum serotonin are associated with a reduction in the tonic phase of a convulsive seizure (154). Furthermore, interictal serum serotonin levels are associated with shorter PGES (154). In the DBA/1 mouse model of seizure induced respiratory arrest, administration of the SSRIs fluoxetine, fluvoxamine, paroxetine, sertraline, and fluoxetine prevent respiratory arrest and death (155-158). The likelihood of seizure induced respiratory arrest is also reduced by administration of 5-hydroxytryptophan, a molecule required in serotonin synthesis (159). Conversely, serotonin antagonism increases the likelihood of seizure induced respiratory arrest consequent to audiogenic seizures (157). Seizures are more severe and more likely to be fatal in mice with a genetic deletion of serotonin neurons in the central nervous system $\left(\operatorname{Lm} \times 1 b^{f / f / p}\right)$ mice vs. wild type counterparts. Seizure induced death is reduced following MES by SSRIs and $5-\mathrm{HT}_{2 \mathrm{~A}}$ receptor agonists, but not a $5-\mathrm{HT}_{2 \mathrm{C}}$ agonist (160). Times in which serotonergic activity is lower, such as the during the night, may lower seizure threshold and make seizures which do occur more dangerous (149, 161, 162)

\section{Adenosine}

Adenosine is a purinergic transmitter which is found in many brain areas and known for its role in sleep-wake regulation, breathing, epilepsy, and a variety of other diseases (163166). Adenosine accumulation and clearance is regulated in a circadian fashion in a variety of brain areas [Figure 4, (146148, 167)]. Adenosine levels increase during wakefulness and are depleted during sleep $(163,168)$. The sleep disturbances often associated with epilepsy may be explained by alterations in adenosine signaling (169). Adenosine is an endogenous anticonvulsant and adenosine levels increase during seizures (170, 171). Furthermore, manipulations to adenosine or its clearance modulate epileptogenesis (171-173). Having recurrent seizures may, in turn, decrease, or increase adenosine levels in different brain areas (169). Adenosine analogs applied to the brainstem of rats cause prolonged suppression of breathing (174, 175). Adenosine analogs administered intracerebroventricularly decrease respiration and elicits apnea in cats (176). Inhibition of adenosine clearance initially prevents the escalating severity of motor seizures following kainate injection; however, the adenosine kinase inhibited animals quickly progress to more severe motor seizures and invariably die, whereas animals not subjected to adenosine kinase inhibition do not die. Treating with caffeine following seizure onset prolongs survival in mice subjected to inhibition of adenosine clearance prior to seizure induction with kainate (177). These results suggest that an unchecked surge in adenosine consequent to a seizure may result in precariously increased levels of neuronal inhibition and thereby facilitate death (177).

\section{Norepinephrine}

Norepinephrine, a catecholaminergic neurotransmitter found in the rostral brainstem including in the locus coeruleus, modulates seizure activity, (178) breathing, (179), and is subject to circadian regulation in an array of different brain areas [Figure 4, (132, 143-145)]. Like serotonin, norepinephrine promotes wakefulness and is an important part of the ascending arousal system (180). In DBA/1 mice, the selective norepinephrine reuptake inhibitor venlafaxine and the SSRIs fluoxetine and fluvoxamine, which also potentiate noradrenergic activity, are more effective in preventing seizure induced respiratory arrest 


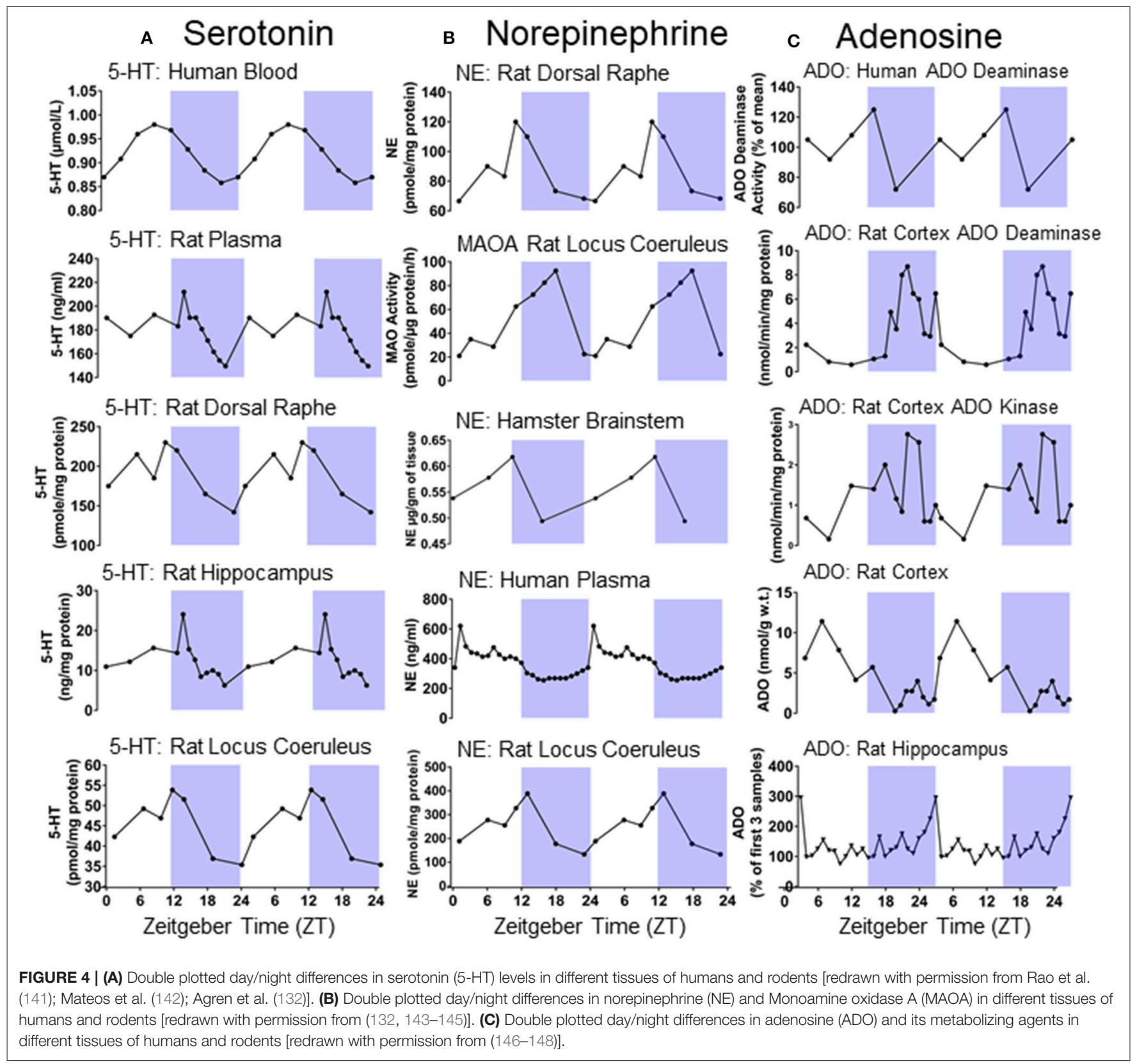

than the selective SSRI paroxetine $(155,157)$. Respiratory arrest is also reduced in DBA/1 mice with the norepinephrine reuptake inhibitor atomoxetine $(181,182)$. In light of this evidence, times at which noradrenergic tone is low might make seizure induced respiratory arrest more likely.

\section{SUMMARY}

The reason that SUDEP happens more during the night is likely multifactorial involving both situational factors, such as being unattended, and physiological changes due to the influence of sleep and circadian rhythms. Human studies suggest that being without a witness and prone following a seizure, which is more likely during the night, might increase risk for nocturnal SUDEP. At the same time, experimentation in animal models and observation of human seizures indicate that both sleep and circadian phase may adversely affect postictal cardiovascular recovery. Sleep and circadian phase have additive effects on breathing which may compound in some way to produce a hazardous postictal state. Similarly, it may be that sleep, and circadian phase have additive effects on vulnerability to seizure induced respiratory arrest. When the factors associated with being without a witness and prone are added to the mix along with the potential effects of sleep and circadian phase SUDEP might be more likely (Figure 5).

Altering the circumstances in which a seizure occurs is currently the best way for reducing the probability of nocturnal 


\section{Potential Day/Night Factors Which May Alter SUDEP Probability}

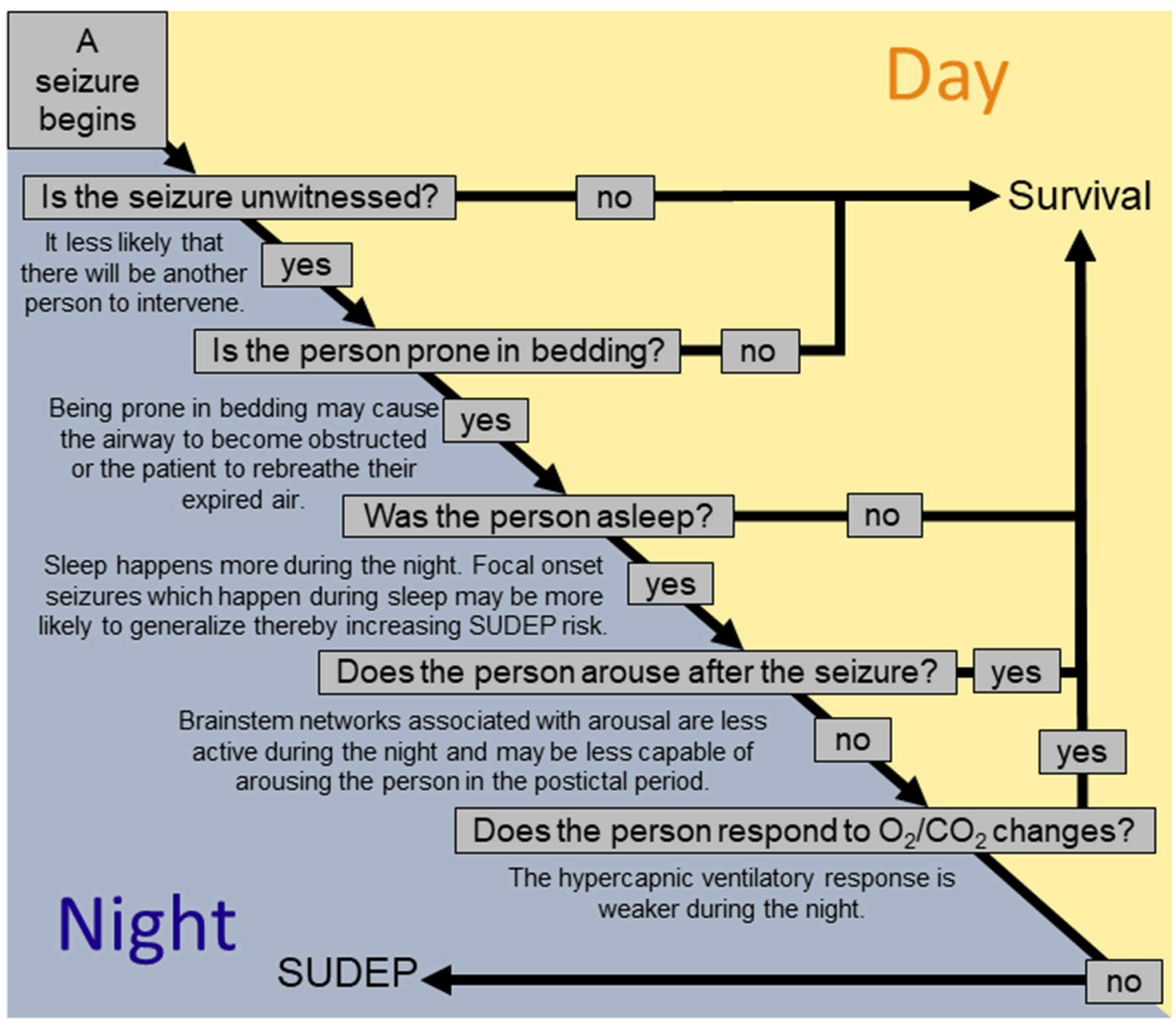

FIGURE 5 | A schematic representation of how different factors relevant to the night might alter the likelihood that a seizure results in SUDEP.

SUDEP, but it is not enough. Patients who do not sleep alone or are being monitored by the use of a device seem to be somewhat protected against SUDEP; however, numerous SUDEP cases have occurred in the direct presence of medical professionals and none of their interventions were sufficient to prevent death. Families and caregivers should be educated about SUDEP and given instruction in basic seizure first aid; however, it should be made abundantly clear that such interventions might be sufficient to prevent death, but it might not and those who have lost someone due to SUDEP are in no way at fault. The risk of SUDEP, nocturnal and otherwise, should be taken into account by patients considering any choice which might alter their likelihood of having a seizure such as adherence, titrating off their medications, switching medication, or pursuing surgical interventions or other non-pharmacological measures.

\section{AUTHOR CONTRIBUTIONS}

BP drafted the initial document which was edited by RT, GB, and BP.

\section{FUNDING}

This work was supported by National Institutes of Health Grants R01NS095842 (to GB), and F31 NS106819 (to BP), Dutch Epilepsy Fund 15-10 (to RT), the Netherlands Organization for Health Research and Development 4041200-98-9335 (to RT), the Christelijke Vereniging voor de Verpleging van Lijders aan Epilepsie, The Netherlands (to RT), and the Beth Levitt Tross Fund for Epilepsy Research (to GB). 


\section{REFERENCES}

1. Opeskin K, Berkovic SF. Risk factors for sudden unexpected death in epilepsy: a controlled prospective study based on coroners cases. Seizure (2003) 12:456-64. doi: 10.1016/S1059-1311(02)00352-7

2. Langan Y, Nashef L, Sander JW. Case-control study of SUDEP. Neurology (2005) 64:1131-3. doi: 10.1212/01.WNL.0000156352.61328.CB

3. Jehi L, Najm IM. Sudden unexpected death in epilepsy: impact, mechanisms, and prevention. Cleve Clin J Med (2008) 75 (Suppl. 2):S66-70. doi: 10.3949/ccjm.75.Suppl_2.S66

4. Thurman DJ, Hesdorffer DC, French JA. Sudden unexpected death in epilepsy: assessing the public health burden. Epilepsia (2014) 55:1479-85. doi: 10.1111/epi.12666

5. Devinsky O, Hesdorffer DC, Thurman DJ, Lhatoo S, Richerson G. Sudden unexpected death in epilepsy: epidemiology, mechanisms, and prevention. Lancet Neurol. (2016) 15:1075-88. doi: 10.1016/S1474-4422(16)30158-2

6. Ryvlin P, Montavont A, Kahane P. Sudden unexpected death in epilepsy: from mechanisms to prevention. Curr Opin Neurol. (2006) 19:194-9. doi: 10.1097/01.wco.0000218238.90711.f4

7. Massey CA, Sowers LP, Dlouhy BJ, Richerson GB. Mechanisms of sudden unexpected death in epilepsy: the pathway to prevention. Nat Rev Neurol. (2014) 10:271-82. doi: 10.1038/nrneurol. 2014.64

8. Dlouhy BJ, Gehlbach BK, Richerson GB. Sudden unexpected death in epilepsy: basic mechanisms and clinical implications for prevention. J Neurol Neurosurg Psychiatry (2016) 87:402-13. doi: 10.1136/jnnp-2013-307442

9. Aiba I, Noebels JL. Spreading depolarization in the brainstem mediates sudden cardiorespiratory arrest in mouse SUDEP models. Sci Transl Med. (2015) 7:282. doi: 10.1126/scitranslmed.aaa4050

10. Ryvlin P, Nashef L, Lhatoo SD, Bateman LM, Bird J, Bleasel A, et al. Incidence and mechanisms of cardiorespiratory arrests in epilepsy monitoring units, (MORTEMUS): a retrospective study. Lancet Neurol. (2013) 12:966-77. doi: 10.1016/S1474-4422(13)70214-X

11. Hesdorffer., Tomson T, Benn E, Sander JW, Nilsson L, Langan Y, et al. Combined analysis of risk factors for SUDEP. Epilepsia (2011) 52:1150-9. doi: $10.1111 / j .1528-1167.2010 .02952 . x$

12. Lamberts RJ, Thijs RD, Laffan A, Langan Y, Sander JW. Sudden unexpected death in epilepsy: people with nocturnal seizures may be at highest risk. Epilepsia (2012) 53:253-7. doi: 10.1111/j.1528-1167.2011.03360.x

13. Ali WS, Issa NP, Rose S, Towle VL, Warnke P, TaoJX. Association of sleep with sudden unexpected death in epilepsy. Epilepsy Behav. (2017) 76:1-6. doi: 10.1016/j.yebeh.2017.08.021

14. van der Lende M, Hesdorffer DC, Sander JW, Thijs RD. Nocturnal supervision and SUDEP risk at different epilepsy care settings. Neurology (2018). doi: 10.1212/WNL.0000000000006356

15. Browne KF, Prystowsky E, Heger JJ, Chilson DA, Zipes DP. Prolongation of the Q-T interval in man during sleep. Am J Cardiol. (1983) 52:55-9. doi: 10.1016/0002-9149(83)90068-1

16. Spengler CM, Shea SA. Endogenous circadian rhythm of pulmonary function in healthy humans. Am J Respir Crit Care Med. (2000) 162:1038-46. doi: 10.1164/ajrccm.162.3.9911107

17. Stephenson LKS, Hamrahi H, Horner RL. Circadian rhythms and sleep have additive effects on respiration in the rat. J Physiol. (2001) 536:225-35. doi: 10.1111/j.1469-7793.2001.00225.x

18. Mortola. Breathing around the clock: an overview of the circadian pattern of respiration. Eur J Appl Physiol. (2004) 91:119-29. doi: 10.1007/s00421-003-0978-0

19. Stephenson. Circadian rhythms and sleep-related breathing disorders. Sleep Med. (2007) 8:681-7. doi: 10.1016/j.sleep.2006.11.009

20. Buchanan GF. Timing, sleep, and respiration in health and disease. Prog Mol Biol Transl Sci. (2013) 119:191-219. doi: 10.1016/B978-0-12-396971-2.00008-7

21. Nobili L, Proserpio P, Rubboli G, Montano N, Didato G, Tassinari CA. Sudden unexpected death in epilepsy, (SUDEP) and sleep. Sleep Med Rev. (2011) 15:237-46. doi: 10.1016/j.smrv.2010.07.006

22. Nashef L, So EL, Ryvlin P, Tomson T. Unifying the definitions of sudden unexpected death in epilepsy. Epilepsia (2012) 53:227-33. doi: $10.1111 /$ j.1528-1167.2011.03358.x
23. Rugg-Gunn F, Duncan J, Hjalgrim H, Seyal M, Bateman L. From unwitnessed fatality to witnessed rescue: Nonpharmacologic interventions in sudden unexpected death in epilepsy. Epilepsia (2016) 57 (Suppl. 1):26-34. doi: 10.1111/epi.13231

24. Blachut B, Hoppe C, Surges R, Stahl J, Elger CE, Helmstaedter C. Counting seizures: the primary outcome measure in epileptology from the patients' perspective. Seizure (2015) 29:97-103. doi: 10.1016/j.seizure.2015.03.004

25. Witek N, Cornes S, Hegde M. Staff response times in the epilepsy monitoring unit: a study of diurnal/nocturnal variability. Neurodiagn J. (2017) 57:269-75. doi: $10.1080 / 21646821.2017 .1357422$

26. Seyal M, Bateman LM, Li CS. Impact of periictal interventions on respiratory dysfunction, postictal EEG suppression, and postictal immobility. Epilepsia (2013) 54:377-82. doi: 10.1111/j.1528-1167.2012.03691.x

27. Assi EB, Nguyen DK, Rihana S, Sawan M. Towards accurate prediction of epileptic seizures: a review. Biomed Signal Proces. (2017) 34:144-57. doi: 10.1016/j.bspc.2017.02.001

28. Van de. Vel A, Cuppens K, Bonroy B, Milosevic M, Jansen K, Van Huffel S, et al. Non-EEG seizure-detection systems and potential SUDEP prevention: state of the art. Seizure (2013) 22:345-55. doi: 10.1016/j.seizure.2013.02.012

29. van Andel J, Thijs RD, de Weerd A, Arends J, Leijten F. Non-EEG based ambulatory seizure detection designed for home use: what is available and how will it influence epilepsy care? Epilepsy Behav. (2016) 57:82-9. doi: 10.1016/j.yebeh.2016.01.003

30. van der Lende M, Cox FM, Visser GH, Sander JW, Thijs RD. Value of video monitoring for nocturnal seizure detection in a residential setting. Epilepsia (2016) 57:1748-53. doi: 10.1111/epi.13558

31. Geertsema EE, Thijs RD, Gutter T, Vledder B, Arends JB, Leijten FS, et al. Automated video-based detection of nocturnal convulsive seizures in a residential care setting. Epilepsia (2018) 59 (Suppl. 1):53-60. doi: 10.1111/epi.14050

32. Jory C, Shankar R, Coker D, McLean B, Hanna J, Newman C. Safe and sound? A systematic literature review of seizure detection methods for personal use. Seizure (2016) 36:4-15. doi: 10.1016/j.seizure.2016.01.013

33. Maguire MJ, Jackson CF, Marson AG, Nolan SJ. Treatments for the prevention of Sudden Unexpected Death in Epilepsy, (SUDEP). Cochrane Database Syst Rev. (2016) 7:CD011792. doi: 10.1002/14651858.CD011792.pub2

34. Langan Y, Nashef L, Sander JW. Sudden unexpected death in epilepsy: a series of witnessed deaths. J Neurol Neurosurg Psychiatry (2000) 68:211-3. doi: $10.1136 /$ jnnp.68.2.211

35. Lhatoo SD, Nei M, Raghavan M, Sperling M, Zonjy B, Lacuey N, et al. Nonseizure SUDEP: sudden unexpected death in epilepsy without preceding epileptic seizures. Epilepsia (2016) 57:1161-8. doi: 10.1111/epi.13419

36. Earnest MP, Thomas GE, Eden RA, Hossack KF. The sudden unexplained death syndrome in epilepsy: demographic, clinical, and postmortem features. Epilepsia (1992) 33:310-6. doi: 10.1111/j.1528-1157.1992.tb02321.x

37. Kloster R, Engelskjon T. Sudden unexpected death in epilepsy, (SUDEP): a clinical perspective and a search for risk factors. J Neurol Neurosurg Psychiatry (1999) 67:439-44. doi: 10.1136/jnnp.67.4.439

38. Zhuo L, Zhang Y, Zielke HR, Levine B, Zhang X, Chang L, et al. Sudden unexpected death in epilepsy: evaluation of forensic autopsy cases. Forensic Sci Int. (2012) 223:171-5. doi: 10.1016/j.forsciint.2012.08.024

39. Shmuely S, Surges R, Sander JW, Thijs RD. Prone sleeping and SUDEP risk: the dynamics of body positions in nonfatal convulsive seizures. Epilepsy Behav (2016) 62:176-9. doi: 10.1016/j.yebeh.2016.06.017

40. Tao JX, Qian S, Baldwin M, Chen XJ, Rose S, Ebersole SH, et al. SUDEP, suspected positional airway obstruction, and hypoventilation in postictal coma. Epilepsia (2010) 51:2344-7. doi: 10.1111/j.1528-1167.2010.02719.x

41. Nashef L, Garner S, Sander JW, Fish DR, Shorvon SD. Circumstances of death in sudden death in epilepsy: interviews of bereaved relatives. J Neurol Neurosurg Psychiatry (1998) 64:349-52. doi: 10.1136/jnnp.64.3.349

42. Thom M, Michalak Z, Wright G, Dawson T, Hilton D, Joshi A, et al. Audit of practice in sudden unexpected death in epilepsy, (SUDEP) post mortems and neuropathological findings. Neuropathol Appl Neurobiol. (2016) 42:463-76. doi: $10.1111 /$ nan. 12265

43. Kemp JS, Nelson VE, Thach BT. Physical-properties of bedding that may increase risk of sudden-infant-death-syndrome in prone-sleeping infants. Pediatr Res. (1994) 36:7-11. doi: 10.1203/00006450-199407001-00002 
44. Liebenthal JA, Wu S, Rose S, Ebersole JS, Tao JX. Association of prone position with sudden unexpected death in epilepsy. Neurology (2015) 84:703-9. doi: 10.1212/WNL.0000000000001260

45. Kuo J, Zhao W, Li CS, Kennedy JD, Seyal M. Postictal immobility and generalized EEG suppression are associated with the severity of respiratory dysfunction. Epilepsia (2016) 57:412-7. doi: 10.1111/epi.13312

46. Catcheside PG, Mohtar AA, Reynolds KJ. Airflow resistance and CO2 rebreathing properties of anti-asphyxia pillows designed for epilepsy. Seizure (2014) 23:462-7. doi: 10.1016/j.seizure.2014.03.007

47. Pollack HA, Frohna JG. Infant sleep placement after the back to sleep campaign. Pediatrics (2002) 109:608-14. doi: 10.1542/peds.109.4.608

48. Tao JX, Sandra R, Wu S, Ebersole JS. Should the "Back to Sleep" campaign be advocated for SUDEP prevention? Epilepsy Behav. (2015) 45:79-80. doi: 10.1016/j.yebeh.2015.02.020

49. Kuna ST, Smickley JS, Insalaco G. Posterior cricoarytenoid muscle activity during wakefulness and sleep in normal adults. J Appl Physiol. (1990) 68:1746-54. doi: 10.1152/jappl.1990.68.4.1746

50. Lo YL, Jordan AS, Malhotra A, Wellman A, Heinzer RA, Eikermann M, et al. Influence of wakefulness on pharyngeal airway muscle activity. Thorax (2007) 62:799-805. doi: 10.1136/thx.2006.072488

51. Douglas NJ, White DP, Pickett CK, Weil JV, Zwillich CW. Respiration during sleep in normal man. Thorax (1982) 37:840-4. doi: 10.1136/thx.37.11.840

52. Reed DJ, Kellogg RH. Changes in respiratory response to $\mathrm{CO} 2$ during natural sleep at sea level and at altitude. J Appl Physiol. (1958) 13:325-30. doi: 10.1152/jappl.1958.13.3.325

53. Robin ED, Whaley RD, Crump CH, Travis DM. Alveolar gas tensions, pulmonary ventilation and blood $\mathrm{pH}$ during physiologic sleep in normal subjects. J Clin Invest. (1958) 37:981-9. doi: 10.1172/JCI103694

54. Birchfield RI, Sieker HO, Heyman A. Alterations in respiratory function during natural sleep. J Lab Clin Med. (1959) 54:216-22.

55. Bulow K. Respiration and wakefulness in man. Acta Physiol Scand Suppl. (1963) 209:1-110.

56. Berthon-Jones M, Sullivan CE. Ventilatory and arousal responses to hypoxia in sleeping humans. Am Rev Respir Dis. (1982) 125:632-9.

57. White DP, Douglas NJ, Pickett CK, Weil JV, Zwillich CW. Hypoxic ventilatory response during sleep in normal premenopausal women. Am Rev Respir Dis. (1982) 126:530-3.

58. Leestma JE, Walczak T, Hughes JR, Kalelkar MB, Teas SS. A prospective study on sudden unexpected death in epilepsy. Ann Neurol. (1989) 26:195203. doi: 10.1002/ana.410260203

59. Tennis P, Cole TB, Annegers JF, Leestma JE, McNutt M, Rajput A. Cohort study of incidence of sudden unexplained death in persons with seizure disorder treated with antiepileptic drugs in Saskatchewan, Canada. Epilepsia (1995) 36:29-36. doi: 10.1111/j.1528-1157.1995.tb01661.x

60. Latreille V, Abdennadher M, Dworetzky BA, Ramel J, White D, Katz E, et al. Nocturnal seizures are associated with more severe hypoxemia and increased risk of postictal generalized EEG suppression. Epilepsia (2017) 58:e127-31. doi: 10.1111/epi.13841

61. Tavernor SJ, Brown SW, Tavernor RME, Gifford C. Electrocardiograph QT lengthening associated with epileptiform EEG discharges-a role in sudden unexplained death in epilepsy? Seizure (1996) 5:79-83. doi: 10.1016/S1059-1311(96)80067-7

62. Biet M, Morin N, Lessard-Beaudoin M, Graham RK, Duss S, Gagne J, et al. Prolongation of action potential duration and QT interval during epilepsy linked to increased contribution of neuronal sodium channels to cardiac late $\mathrm{Na}+$ current: potential mechanism for sudden death in epilepsy. Circ Arrhythm Electrophysiol. (2015) 8:912-20. doi: 10.1161/CIRCEP.114.002693

63. Nei M, Ho RT, Abou-Khalil BW, Drislane FW, Liporace J, Romeo A, et al. EEG and ECG in sudden unexplained death in epilepsy. Epilepsia (2004) 45:338-45. doi: 10.1111/j.0013-9580.2004.05503.x

64. Manni R, Terzaghi M. Comorbidity between epilepsy and sleep disorders. Epilepsy Res. (2010) 90:171-7. doi: 10.1016/j.eplepsyres.2010.05.006

65. McCarter AR, Timm PC, Shepard PW, Sandness DJ, Luu T, McCarter SJ, et al. Obstructive sleep apnea in refractory epilepsy: a pilot study investigating frequency, clinical features, and association with risk of sudden unexpected death in epilepsy. Epilepsia (2018) 59:1973-81. doi: 10.1111/epi.14548

66. Gami AS, Olson EJ, Shen WK, Wright RS, Ballman KV, Hodge DO, et al. Obstructive sleep apnea and the risk of sudden cardiac death: a longitudinal study of 10,701 adults. J Am Coll Cardiol. (2013) 62:610-6. doi: 10.1016/j.jacc.2013.04.080

67. Gami AS, Howard DE, Olson EJ, Somers VK. Day-night pattern of sudden death in obstructive sleep apnea. N Engl J Med. (2005) 352:1206-14. doi: 10.1056/NEJMoa041832

68. Clark RW, Boudoulas H, Schaal SF, Schmidt HS. Adrenergic hyperactivity and cardiac abnormality in primary disorders of sleep. Neurology (1980) 30:113-9. doi: 10.1212/WNL.30.2.113

69. Somers VK, Dyken ME, Clary MP, Abboud FM. Sympathetic neural mechanisms in obstructive sleep apnea. J Clin Invest. (1995) 96:1897-904. doi: 10.1172/JCI118235

70. Guardiola J, Yu J, Hasan N, Fletcher EC. Evening and morning blood gases in patients with obstructive sleep apnea. Sleep Med. (2004) 5:489-93. doi: 10.1016/j.sleep.2004.05.004

71. Minecan D, Natarajan A, Marzec M, Malow B. Relationship of epileptic seizures to sleep stage and sleep depth. Sleep (2002) 25:899-904. doi: 10.1093/sleep/25.8.56

72. $\mathrm{Ng} \mathrm{M}$, Pavlova M. Why are seizures rare in rapid eye movement sleep? Review of the frequency of seizures in different sleep stages. Epilepsy Res Treat (2013) 2013:932790. doi: 10.1155/2013/932790

73. Bazil CW, Walczak TS. Effects of sleep and sleep stage on epileptic and nonepileptic seizures. Epilepsia (1997) 38:56-62. doi: 10.1111/j.1528-1157.1997.tb01077.x

74. Crespel A, Baldy-Moulinier M, Coubes P. The relationship between sleep and epilepsy in frontal and temporal lobe epilepsies: Practical and physiopathologic considerations. Epilepsia (1998) 39:150-7. doi: 10.1111/j.1528-1157.1998.tb01352.x

75. Pavlova MK, Shea SA, Bromfield EB. Day/night patterns of focal seizures. Epilepsy Behav. (2004) 5:44-9. doi: 10.1016/j.yebeh.2003.10.013

76. Opherk C, Coromilas J, Hirsch LJ. Heart rate and EKG changes in 102 seizures: analysis of influencing factors. Epilepsy Res. (2002) 52:117-27. doi: 10.1016/S0920-1211(02)00215-2

77. Lamberts RJ, Gaitatzis A, Sander JW, Elger CE, Surges R, Thijs RD. Postictal generalized EEG suppression: an inconsistent finding in people with multiple seizures. Neurology (2013) 81:1252-6. doi: 10.1212/WNL.0b013e3182a6cbeb

78. Lamberts RJ, Laranjo S, Kalitzin SN, Velis DN, Rocha I, Sander JW, et al. Postictal generalized EEG suppression is not associated with periictal cardiac autonomic instability in people with convulsive seizures. Epilepsia (2013) 54:523-9. doi: 10.1111/epi.12021

79. Alexandre V, Mercedes B, Valton L, Maillard L, Bartolomei F, Szurhaj W, et al. Risk factors of postictal generalized EEG suppression in generalized convulsive seizures. Neurology (2015) 85:1598-603. doi: 10.1212/WNL.0000000000001949

80. Okanari K, Otsubo H, Kouzmitcheva E, Rangrej J, Baba S, Ochi A, et al. Ictal symmetric tonic extension posturing and postictal generalized EEG suppression arising from sleep in children with epilepsy. Pediatr Neurol. (2017) 76:54-9. doi: 10.1016/j.pediatrneurol.2017.06.018

81. Lee A, Wu S, Zhou X, Liebenthal J, Rose S, Tao JX. Periictal autonomic dysfunction and generalized postictal EEG suppression in convulsive seizures arising from sleep and wakefulness. Epilepsy Behav. (2013) 28:43943. doi: 10.1016/j.yebeh.2013.06.010

82. Kang JY, Rabiei AH, Myint L, Nei M. Equivocal significance of post-ictal generalized EEG suppression as a marker of SUDEP risk. Seizure-Eur J Epilep. (2017) 48:28-32. doi: 10.1016/j.seizure.2017.03.017

83. Peng W, Danison JL, Seyal M. Postictal generalized EEG suppression and respiratory dysfunction following generalized tonic-clonic seizures in sleep and wakefulness. Epilepsia (2017) 58:1409-14. doi: 10.1111/epi.13805

84. Hajek MA, Buchanan GF. Influence of vigilance state on physiological consequences of seizures and seizure-induced death in mice. J Neurophysiol. (2016) 115:2286-93. doi: 10.1152/jn.00011.2016

85. Shouse MN, Siegel JM, Wu MF, Szymusiak R, Morrison AR. Mechanisms of seizure suppression during rapid-eye-movement, (REM) sleep in cats. Brain Res. (1989) 505:271-82. doi: 10.1016/0006-8993(89)91453-4

86. Sedigh-Sarvestani M, Thuku GI, Sunderam S, Parkar A, Weinstein SL, Schiff SJ, et al. Rapid eye movement sleep and hippocampal theta oscillations precede seizure onset in the tetanus toxin model of temporal lobe epilepsy. J Neurosci. (2014) 34:1105-14. doi: 10.1523/JNEUROSCI.310313.2014 
87. Iyer SH, Matthews SA, Simeone TA, Maganti R, Simeone KA. Accumulation of rest deficiency precedes sudden death of epileptic Kv1.1 knockout mice, a model of sudden unexpected death in epilepsy. Epilepsia (2018) 59:92-105. doi: 10.1111/epi.13953

88. Spengler CM, Czeisler CA, Shea SA. An endogenous circadian rhythm of respiratory control in humans. J Physiol. (2000) 526 (Pt 3):683-94. doi: 10.1111/j.1469-7793.2000.00683.x

89. Adamczyk W, Tafil-Klawe M, Siekierka M, Zlomanczuk P, Weber P, Klawe JJ. Daily pattern of breathing in healthy young men. J Physiol Pharmacol. (2008) 59 (Suppl. 6):115-22. Available online at: http://www.jpp.krakow.pl/journal/ archive/12_08_s6/pdf/115_12_08_s6_article.pdf

90. Peever JH, Stephenson R. Day-night differences in the respiratory response to hypercapnia in awake adult rats. Respir Physiol. (1997) 109:241-8. doi: 10.1016/S0034-5687(97)00056-X

91. Seifert EL, Mortola JP. The circadian pattern of breathing in conscious adult rats. Respir Physiol. (2002) 129:297-305. doi: 10.1016/S0034-5687(01)00316-4

92. Stephenson MRM, Duffin J, Jarsky TM. Circadian rhythms in the chemoreflex control of breathing. Am J Physiol Regul Integr Comp Physiol. (2000) 278:R282-286. doi: 10.1152/ajpregu.2000.278.1.R282

93. Raschke, Möller. Untersuchungen zur tagersrhythmik der chesensitivität und daren beitrag zu nächtlichen atmungsregulationsstörungen. Pneumology (1989) 43:568-71.

94. Meyer JS, Gotoh F, Favale E. Cerebral metabolism during epileptic seizures in man. Electroencephalogr Clin Neurophysiol. (1966) 21:10-22. doi: 10.1016/0013-4694(66)90054-X

95. Bateman LM, Li CS, Lin TC, Seyal M. Serotonin reuptake inhibitors are associated with reduced severity of ictal hypoxemia in medically refractory partial epilepsy. Epilepsia (2010) 51:2211-4. doi: 10.1111/j.1528-1167.2010.02594.x

96. Seyal M, Hardin KA, Bateman LM. Postictal generalized EEG suppression is linked to seizure-associated respiratory dysfunction but not postictal apnea. Epilepsia (2012) 53:825-31. doi: 10.1111/j.1528-1167.2012.03443.x

97. Dlouhy BJ, Gehlbach BK, Kreple CJ, Kawasaki H, Oya H, Buzza C, et al. Breathing inhibited when seizures spread to the amygdala and upon amygdala stimulation. J Neurosci. (2015) 35:10281-9. doi: 10.1523/JNEUROSCI.0888-15.2015

98. Bando H, Nishio T, van der Horst GT, Masubuchi S, Hisa Y, Okamura H. Vagal regulation of respiratory clocks in mice. J Neurosci. (2007) 27:4359-65. doi: 10.1523/JNEUROSCI.4131-06.2007

99. Butler MP, Smales C, Wu H, Hussain MV, Mohamed YA, Morimoto M, et al. The circadian system contributes to apnea lengthening across the night in obstructive sleep apnea. Sleep (2015) 38:1793-801. doi: 10.5665/sleep.5166

100. Sly PD, Landau LI. Diurnal variation in bronchial responsiveness in asthmatic children. Pediatr Pulmonol. (1986) 2:344-52. doi: 10.1002/ppul.1950020606

101. Syabbalo N. Chronobiology and chronopathophysiology of nocturnal asthma. Int J Clin Pract. (1997) 51:455-62.

102. Durrington HJ, Farrow SN, Loudon AS, Ray DW. The circadian clock and asthma. Thorax (2014) 69:90-2. doi: 10.1136/thoraxjnl-2013-203482

103. Tsai CL, Brenner BE, Carnargo CA. Circadian-rhythm differences among emergency department patients with chronic obstructive pulmonary disease exacerbation. Chronobiology International. (2007) 24:699-713. doi: 10.1080/07420520701535753

104. Daltveit AK, Irgens LM, Oyen N, Skjaerven R, Markestad T, Wennergren G. Circadian variations in sudden infant death syndrome: associations with maternal smoking, sleeping position and infections. Nordic Epidemiological SIDS Study Acta Paediatr. (2003) 92:1007-13. doi: 10.1111/j.1651-2227.2003.tb02567.x

105. Richerson GB, Buchanan GF. The serotonin axis: Shared mechanisms in seizures, depression, and SUDEP. Epilepsia (2011) 52 (Suppl. 1):28-38. doi: 10.1111/j.1528-1167.2010.02908.x

106. Buijs R. M., la Fleur SE, Wortel J, Van Heyningen C, Zuiddam L, Mettenleiter $\mathrm{TC}$, et al. The suprachiasmatic nucleus balances sympathetic and parasympathetic output to peripheral organs through separate preautonomic neurons. J Comp Neurol. (2003) 464:36-48. doi: 10.1002/cne.10765

107. Mutoh T, Shibata S, Korf HW, Okamura H. Melatonin modulates the light-induced sympathoexcitation and vagal suppression with participation of the suprachiasmatic nucleus in mice. J Physiol. (2003) 547:317-32. doi: 10.1113/jphysiol.2002.028001

108. Joustra SD, Reijntjes RH, Pereira AM, Lammers GJ, Biermasz NR, Thijs RD. The role of the suprachiasmatic nucleus in cardiac autonomic control during sleep. PLoS ONE (2016) 11: e0152390. doi: 10.1371/journal.pone.0152390

109. Shaffer F, McCraty R, Zerr CL. A healthy heart is not a metronome: an integrative review of the heart's anatomy and heart rate variability. Front Psychol. (2014) 5:1040. doi: 10.3389/fpsyg.2014.01040

110. Eppinger N, Schaumann R, Jokeit H, Buettner UW, Kraemer G. Reduced heart rate variability, (HRV) in victims of sudden death in epilepsy, (SUDEP). Epilepsia (2004) 45:65.

111. Surges R, Adjei P, Kallis C, Erhuero J, Scott CA, Bell GS, et al. Pathologic cardiac repolarization in pharmacoresistant epilepsy and its potential role in sudden unexpected death in epilepsy: a case-control study. Epilepsia (2010) 51:233-42. doi: 10.1111/j.1528-1167.2009.02330.x

112. Myers KA, Bello-Espinosa LE, Symonds JD, Zuberi SM, Clegg R, Sadleir LG, et al. Heart rate variability in epilepsy: a potential biomarker of sudden unexpected death in epilepsy risk. Epilepsia (2018) 59:1372-80. doi: 10.1111/epi.14438

113. Boudreau P, Yeh WH, Dumont GA, Boivin DB. A circadian rhythm in heart rate variability contributes to the increased cardiac sympathovagal response to awakening in the morning. Chronobiol Int. (2012) 29:757-68. doi: 10.3109/07420528.2012.674592

114. Niemeijer ND, Corssmit EP, Reijntjes RH, Lammers GJ, van Dijk JG, Thijs RD. Sleep-mediated heart rate variability after bilateral carotid body tumor resection. Sleep (2015) 38:633-9. doi: 10.5665/sleep.4586

115. Ronkainen E, Ansakorpi H, Huikuri HV, Myllyla VV, Isojarvi JI, Korpelainen JT. Suppressed circadian heart rate dynamics in temporal lobe epilepsy. J Neurol Neurosurg Psychiatry (2005) 76:1382-6. doi: 10.1136/jnnp.2004.053777

116. Persson H, Kumlien E, Ericson M, Tomson T. Circadian variation in heartrate variability in localization-related epilepsy. Epilepsia (2007) 48:917-22. doi: 10.1111/j.1528-1167.2006.00961.x

117. Ramet J, Hauser B, Waldura J, De Prins J. Circadian rhythm of cardiac responses to vagal stimulation tests. Pediatr Neurol. (1992) 8:91-6. doi: 10.1016/0887-8994(92)90027-V

118. Lamberts RJ, Blom MT, Wassenaar M, Bardai A, Leijten FS, de Haan GJ, et al. Sudden cardiac arrest in people with epilepsy in the community: circumstances and risk factors. Neurology (2015) 85:212-8. doi: 10.1212/WNL.0000000000001755

119. Shmuely S, van der Lende M, Lamberts RJ, Sander JW, Thijs RD. The heart of epilepsy: Current views and future concepts. Seizure (2017) 44:176-83. doi: 10.1016/j.seizure.2016.10.001

120. Bonnemeier H, Wiegand UK, Braasch W, Brandes A, Richardt G, Potratz J. Circadian profile of QT interval and QT interval variability in 172 healthy volunteers. Pacing Clin Electrophysiol. (2003) 26:377-82. doi: 10.1046/j.1460-9592.2003.00053.x

121. Quigg M, Straume M, Menaker M, Bertram EH III. Temporal distribution of partial seizures: comparison of an animal model with human partial epilepsy. Ann Neurol. (1998) 43:748-55. doi: 10.1002/ana.410430609

122. Quigg M. Circadian rhythms: interactions with seizures and epilepsy. Epilepsy Res. (2000) 42:43-55. doi: 10.1016/S0920-1211(00)00157-1

123. Hofstra WA, de Weerd AW. The circadian rhythm and its interaction with human epilepsy: a review of literature. Sleep Med Rev. (2009) 13:413-20. doi: 10.1016/j.smrv.2009.01.002

124. Loddenkemper T, Vendrame M, Zarowski M, Gregas M, Alexopoulos AV, Wyllie E, et al. Circadian patterns of pediatric seizures. Neurology (2011) 76:145-53. doi: 10.1212/WNL.0b013e318206ca46

125. Ramgopal S, Vendrame M, Shah A, Gregas M, Zarowski M, Rotenberg A, et al. Circadian patterns of generalized tonic-clonic evolutions in pediatric epilepsy patients. Seizure (2012) 21:535-9. doi: 10.1016/j.seizure.2012. 05.011

126. Spencer DC, Sun FT, Brown SN, Jobst BC, Fountain NB, Wong VS, et al. Circadian and ultradian patterns of epileptiform discharges differ by seizureonset location during long-term ambulatory intracranial monitoring. Epilepsia (2016) 57:1495-502. doi: 10.1111/epi.13455

127. Zarowski M, Loddenkemper $\mathrm{T}$, Vendrame $\mathrm{M}$, Alexopoulos AV, Wyllie E, Kothare SV. Circadian distribution and sleep/wake patterns 
of generalized seizures in children. Epilepsia (2011) 52:1076-83. doi: $10.1111 / j .1528-1167.2011 .03023 . x$

128. Durazzo TS, Spencer SS, Duckrow RB, Novotny EJ, Spencer DD, Zaveri HP. Temporal distributions of seizure occurrence from various epileptogenic regions. Neurology (2008) 70:1265-71. doi: 10.1212/01.wnl.0000308938.84918.3f

129. Lamont EW, Robinson B, Stewart J, Amir S. The central and basolateral nuclei of the amygdala exhibit opposite diurnal rhythms of expression of the clock protein Period2. Proc Natl Acad Sci USA. (2005) 102:4180-4. doi: $10.1073 /$ pnas. 0500901102

130. Baud MO, Kleen JK, Mirro EA, Andrechak JC, King-Stephens D, Chang EF, et al. Multi-day rhythms modulate seizure risk in epilepsy. Nat Commun. (2018) 9:1-10. doi: 10.1038/s41467-017-02577-y

131. Schreiber RA, Schlesinger K. Circadian rhythms and seizure susceptibility: relation to 5-hydroxytryptamine and norepinephrine in brain. Physiol Behav. (1971) 6:635-40. doi: 10.1016/0031-9384(71)90247-2

132. Agren H, Koulu M, Saavedra JM, Potter WZ, Linnoila M. Circadian covariation of norepinephrine and serotonin in the locus coeruleus and dorsal raphe nucleus in the rat. Brain Res. (1986) 397:353-8. doi: 10.1016/0006-8993(86)90638-4

133. Moore BM, Jerry Jou C, Tatalovic M, Kaufman ES, Kline DD, Kunze DL. The Kv1.1 null mouse, a model of sudden unexpected death in epilepsy, (SUDEP). Epilepsia (2014) 55:1808-16. doi: 10.1111/epi.12793

134. Purnell BS, Hajek MA, Buchanan GF. Time-of-day influences on respiratory sequelae following maximal electroshock-induced seizures in mice. $J$ Neurophysiol. (2017) 118:2592-600. doi: 10.1152/jn.00039.2017

135. Hornung JP. The human raphe nuclei and the serotonergic system. J Chem Neuroanat. (2003) 26:331-43. doi: 10.1016/j.jchemneu.2003.10.002

136. Morin LP. Serotonin and the regulation of mammalian circadian rhythmicity. Ann Med. (1999) 31:12-33. doi: 10.3109/07853899909019259

137. Ursin R. Serotonin and sleep. Sleep Med Rev. (2002) 6:55-67. doi: $10.1053 /$ smrv.2001.0174

138. Richter DW, Manzke T, Wilken B, Ponimaskin E. Serotonin receptors: guardians of stable breathing. Trends Mol Med. (2003) 9:542-8. doi: 10.1016/j.molmed.2003.10.010

139. Bagdy G, Kecskemeti V, Riba P, Jakus R. Serotonin and epilepsy. J Neurochem. (2007) 100:857-73. doi: 10.1111/j.1471-4159.2006.04277.x

140. Trulson ME, Jacobs BL. Raphe unit activity in freely moving cats: correlation with level of behavioral arousal. Brain Res. (1979) 163:135-50. doi: 10.1016/0006-8993(79)90157-4

141. Rao ML, Gross G, Strebel B, Halaris A, Huber G, Bräunig P, et al. Circadian rhythm of tryptophan, serotonin, melatonin, and pituitary hormones in schizophrenia. Biol Psychiatry (1994) 35:151-63.

142. Mateos SS, Sanchez CL, Paredes SD, Barriga C, Rodriguez AB. Circadian levels of serotonin in plasma and brain after oral administration of tryptophan in rats. Basic Clin Pharmacol Toxicol. (2008) 104:52-9. doi: 10.1111/j.1742-7843.2008.00333.x

143. Linsell CR, Lightman SL, Mullen PE, Brown MJ, Causon RC. Circadian rhythms of epinephrine and norepinephrine in man. J Clin Endocrinol Metab. (1985) 60:1210-5. doi: 10.1210/jcem-60-6-1210

144. Chevillard C, Barden N, Saavedra JM. Twenty-four hour rhythm in monoamine oxidase activity in specific areas of the rat brain stem. Brain Res. (1981) 223:205-9. doi: 10.1016/0006-8993(81)90825-8

145. Morgan WW, McFadin LS, Harvey CY. A daily rhythm in norepinephrine content in regions of the hamster brain. Comp Gen Pharmacol. (1973) 4:47-52. doi: 10.1016/0010-4035(73)90020-7

146. Chagoya de. Sanchez V, Hernandez Munoz R, Suarez J, Vidrio S, Yanez L, Diaz Munoz, M. Day-night variations of adenosine and its metabolizing enzymes in the brain cortex of the rat-possible physiological significance for the energetic homeostasis and the sleep-wake cycle. Brain Res. (1993) 612:115-21. doi: 10.1016/0006-8993(93)91651-8

147. Huston JP, Haas HL, Boix F, Pfister M, Decking U, Schrader J, et al. Extracellular adenosine levels in neostriatum and hippocampus during rest and activity periods of rats. Neuroscience (1996) 73:99-107. doi: 10.1016/0306-4522(96)00021-8

148. Cornelissen G, Touitou Y, Tritsch G, Bogdan A, Auzeby A, Reinberg A, et al. Circadian rhythms of adenosine deaminase activity in human erythrocytes: a transverse study on young, elderly and senile demented subjects. Ric Clin Lab. (1985) 15:365-74.

149. Rosenwasser AM, Trubowitsch G, Adler NT. Circadian rhythm in metabolic activity of suprachiasmatic, supraoptic and raphe nuclei. Neurosci Lett. (1985) 58:183-7. doi: 10.1016/0304-3940(85)90161-2

150. Zhan Q, Buchanan GF, Motelow JE, Andrews J, Vitkovskiy P, Chen WC, et al. Impaired serotonergic brainstem function during and after seizures. J Neurosci. (2016) 36:2711-22. doi: 10.1523/JNEUROSCI.4331-15.2016

151. Buchanan GF, Richerson GB. Central serotonin neurons are required for arousal to CO2. Proc Natl Acad Sci USA. (2010) 107:16354-9. doi: 10.1073/pnas.1004587107

152. Buchanan GF, Smith HR, MacAskill A, Richerson GB. 5-HT2A receptor activation is necessary for CO2-induced arousal. J Neurophysiol. (2015) 114:233-43. doi: 10.1152/jn.00213.2015

153. Smith HR, Leibold NK, Rappoport DA, Ginapp CM, Purnell BS, Bode NM, et al. Dorsal raphe serotonin neurons mediate CO2-induced arousal from sleep. J Neurosci. (2018) 38:1915-25. doi: 10.1523/JNEUROSCI.2182-17.2018

154. Murugesan A, Rani MRS, Hampson J, Zonjy B, Lacuey N, Faingold CL, et al. Serum serotonin levels in patients with epileptic seizures. Epilepsia (2018) 59:e91-e97. doi: 10.1111/epi.14198

155. Faingold CL, Tupal S, Randall M. Prevention of seizure-induced sudden death in a chronic SUDEP model by semichronic administration of a selective serotonin reuptake inhibitor. Epilepsy Behav. (2011) 22:186-90. doi: 10.1016/j.yebeh.2011.06.015

156. Faingold CL, Randall M. Effects of age, sex, and sertraline administration on seizure-induced respiratory arrest in the DBA/1 mouse model of sudden unexpected death in epilepsy, (SUDEP). Epilepsy Behav. (2013) 28:78-82. doi: 10.1016/j.yebeh.2013.04.003

157. Faingold CL, Kommajosyula SP, Long X, Plath K, Randall M. Serotonin and sudden death: differential effects of serotonergic drugs on seizureinduced respiratory arrest in DBA/1 mice. Epilepsy Behav. (2014) 37:198203. doi: 10.1016/j.yebeh.2014.06.028

158. Zeng C, Long X, Cotten JF, Forman SA, Solt K, Faingold CL, et al. Fluoxetine prevents respiratory arrest without enhancing ventilation in DBA/1 mice. Epilepsy Behav. (2015) 45:1-7. doi: 10.1016/j.yebeh.2015.02.013

159. Zhang H, Zhao H, Yang X, Xue Q, Cotten JF, Feng HJ. 5-Hydroxytryptophan, a precursor for serotonin synthesis, reduces seizure-induced respiratory arrest. Epilepsia (2016) 57:1228-35. doi: 10.1111/epi.13430

160. Buchanan GF, Murray NM, Hajek MA, Richerson GB. Serotonin neurones have anti-convulsant effects and reduce seizure-induced mortality. J Physiol. (2014) 592:4395-410. doi: 10.1113/jphysiol.2014.277574

161. Sun X, Deng J, Liu T, Borjigin J. Circadian 5-HT production regulated by adrenergic signaling. Proc Natl Acad Sci USA (2002) 99:4686-91. doi: $10.1073 /$ pnas. 062585499

162. Liu T, Borjigin J. Relationship between nocturnal serotonin surge and melatonin onset in rodent pineal gland. J Circadian Rhythms (2006) 4:12. doi: 10.1186/1740-3391-4-12

163. Bjorness TE, Greene RW. Adenosine and sleep. Curr Neuropharmacol. (2009) 7:238-45. doi: 10.2174/157015909789152182

164. Nobre HVJr, Cunha GM, de Vasconcelos LM, Magalhaes HI, Oliveira Neto RN, Maia FD, et al. Caffeine and CSC, adenosine A2A antagonists, offer neuroprotection against 6-OHDA-induced neurotoxicity in rat mesencephalic cells. Neurochem Int. (2010) 56:51-8. doi: 10.1016/j.neuint.2009.09.001

165. Sperlagh B, Sylvester Vizi E. The role of extracellular adenosine in chemical neurotransmission in the hippocampus and basal ganglia: pharmacological and clinical aspects. Curr Top Med Chem. (2011) 11:103446. doi: 10.2174/156802611795347564

166. Boison D. Adenosine dysfunction in epilepsy. Glia (2012) 60:1234-43. doi: $10.1002 /$ glia. 22285

167. Chagoya de. Sanchez, V. Circadian variations of adenosine and of its metabolism Could adenosine be a molecular oscillator for circadian rhythms? Can J Physiol Pharmacol. (1995) 73:339-55. doi: 10.1139/y95-044

168. Porkka-Heiskanen T. Adenosine in sleep and wakefulness. Ann Med. (2009) 31:125-9. doi: 10.3109/078538999089 98788 
169. Warren TJ, Simeone TA, Smith DD, Grove R, Adamec J, Samson KK, et al. Adenosine has two faces: regionally dichotomous adenosine tone in a model of epilepsy with comorbid sleep disorders. Neurobiol Dis. (2018) 114:45-52. doi: 10.1016/j.nbd.2018.01.017

170. During MJ, Spencer DD. Adenosine: a potential mediator of seizure arrest and postictal refractoriness. Ann Neurol. (1992) 32:618-24. doi: 10.1002/ana.410320504

171. Boison D. Adenosinergic signaling in epilepsy. Neuropharmacology (2016) 104:131-9. doi: 10.1016/j.neuropharm.2015.08.046

172. Gouder N, Scheurer L, Fritschy JM, Boison D. Overexpression of adenosine kinase in epileptic hippocampus contributes to epileptogenesis. J Neurosci. (2004) 24:692-701. doi: 10.1523/JNEUROSCI.4781-03.2004

173. Li T, Ren G, Lusardi T, Wilz A, Lan JQ, Iwasato T, et al. Adenosine kinase is a target for the prediction and prevention of epileptogenesis in mice. J Clin Invest. (2008) 118:571-82. doi: 10.1172/JCI33737

174. Barraco RA, Janusz CA. Respiratory effects of $5^{\prime}=$ ethylcarboxamidoadenosine, an analog of adenosine, following microinjections into the nucleus tractus solitarius of rats. Brain Res. (1989) 480:360-4. doi: 10.1016/0006-8993(89)90208-4

175. Barraco RA, Janusz CA, Schoener EP, Simpson LL. Cardiorespiratory function is altered by picomole injections of 5'-Nethylcarboxamidoadenosine into the nucleus tractus solitarius of rats. Brain Res. (1990) 507:234-46. doi: 10.1016/0006-8993(90)90277-I

176. Eldridge FL, Millhorn DE, Kiley JP. Respiratory effects of a long-acting analog of adenosine. Brain Res. (1984) 301:273-80. doi: 10.1016/0006-8993(84)91096-5

177. Shen HY, Li T, Boison D. A novel mouse model for sudden unexpected death in epilepsy, (SUDEP): role of impaired adenosine clearance. Epilepsia (2010) 51:465-8. doi: 10.1111/j.1528-1167.2009.02248.x
178. Ray M, Mediratta PK, Reeta K, Mahajan P, Sharma KK. Receptor mechanisms involved in the anticonvulsant effect of melatonin in maximal electroshock seizures. Methods Find Exp Clin Pharmacol. (2004) 26:177. doi: 10.1358/mf.2004.26.3.809723

179. Viemari JC, Tryba AK. Bioaminergic neuromodulation of respiratory rhythm in vitro. Respir Physiol Neurobiol. (2009) 168:69-75. doi: 10.1016/j.resp.2009.03.011

180. Mitchell HA, Weinshenker D. Good night and good luck: norepinephrine in sleep pharmacology. Biochem Pharmacol. (2010) 79:801-9. doi: 10.1016/j.bcp.2009.10.004

181. Zhang H, Zhao H, Feng HJ. Atomoxetine, a norepinephrine reuptake inhibitor, reduces seizure-induced respiratory arrest. Epilepsy Behav. (2017) 73:6-9. doi: 10.1016/j.yebeh.2017.04.046

182. Zhao H, Cotten JF, Long X, Feng HJ. The effect of atomoxetine, a selective norepinephrine reuptake inhibitor, on respiratory arrest and cardiorespiratory function in the DBA/1 mouse model of SUDEP. Epilepsy Res. (2017) 137:139-44. doi: 10.1016/j.eplepsyres.2017.08.005

Conflict of Interest Statement: The authors declare that the research was conducted in the absence of any commercial or financial relationships that could be construed as a potential conflict of interest.

Copyright (c) 2018 Purnell, Thijs and Buchanan. This is an open-access article distributed under the terms of the Creative Commons Attribution License (CC BY). The use, distribution or reproduction in other forums is permitted, provided the original author(s) and the copyright owner(s) are credited and that the original publication in this journal is cited, in accordance with accepted academic practice. No use, distribution or reproduction is permitted which does not comply with these terms. 